\title{
PENGELOLAAN CORPORATE SOCIAL RESPONSIBILITY PT. LONSUM DI KECAMATAN UJUNG LOE KABUPATEN BULUKUMBA
}

Almuhajir Haris ${ }^{1}$, Abdul Kadir Adys ${ }^{1}$, Andi Luhur Prianto ${ }^{1}$ 1Program Studi Ilmu Pemerintahan Fakultas Ilmu Sosial dan Ilmu Politik Universitas Muhammadiyah Makassar Jl Sultan Alauddin No 259 Makassar 90221 Telp. 0411-866972 ext. 107. Fax. 0411-8655888 almuhajir@yahoo.co.id kadir adys@yahoo.co.id luhur@unismuh.ac.id

\begin{abstract}
This paper aims to look at the management and the benefits of CSR (Corporate Social Responsibility) PT Lonsum in District Ujung Loe Bulukumba. The method used in this penelitiian is a qualitative description of the approach. The sample in this study as many as 10 people. Data collection techniques in this research is observation, interview, and documentation. The results showed that (a) planning conducted by PT. LonSum in doing a CSR (Corporate Social Responsibility) are correct (b) Implementation of CSR (Corporate Social Responsibility) is felt directly by the people. (C) Supervision in CSR (Corporate Social Responsibility) involved by the government and society (d) The effectiveness of the activity of management of CSR (Corporate Social Responsibility) directional well. (E) The benefits to society kec, Ujung Loe. Kab. Bulukumba. Give benefits in the field of improving the local economy, community empowerment and environmental safety.
\end{abstract}

Keywords: Management, CSR, community empowerment.

\begin{abstract}
ABSTRAK
Tulisan ini bertujuan untuk melihat pengelolaan dan manfaat CSR (Corporate Social Responsibility) PT Lonsum di Kecamatan Ujung Loe Kabupaten Bulukumba. Metode yang digunakan dalam penelitiian ini adalah pendekatan deskripsi kualitatif. Sampel dalam penelitian ini sebanyak 10 orang. Teknik pengumpulan data dalam penelitian ini adalah observasi, wawancara, dan dokumentasi. Hasil penelitian menunjukkan bahwa (a) Perencanaan yang dilakukan oleh PT. LONSUM dalam melakukan suatu kegiatan CSR (Corporate Social Responsibility) sudah tepat (b) Pelaksanaan kegiatan CSR (Corporate Social Responsibility) dirasakan langsung oleh masyarakat. (c) Pengawasan dalam kegiatan CSR (Corporate Social Responsibility) melibatkan oleh pihak pemerintah dan masyarakat (d) Efektifitas pengelolaan kegitan CSR (Corporate Social Responsibility) terarah dengan baik. (e) Manfaat pada masyarakat kec, Ujung Loe. Kab. Bulukumba. Sangat memberikan manfaat dalam bidang peningkatan ekonomi masyarakat, pemberdayaan masyarakat dan keselamatan lingkungan.
\end{abstract}

Kata Kunci: Pengelolaan, CSR, pemberdayaan masyarakat 


\section{A. LATAR BELAKANG}

Tanggung jawab sosial perusahaan atau CSR (Corporate Social Responsibility) mungkin masih kurang popular dikalangan pelaku usaha nasional. Namun, tidak berlaku bagi pelaku usaha asing. Kegiatan sosial kemasyarakatan yang dilakukan secara sukarela itu, sudah biasa dilakukan oleh perusahaan-perusahaan multinasional ratusan tahun lalu.Berbeda dengan kondisi Indonesia, di sini kegiatan CSR (Corporate Social Responsibility) baru dimulai beberapa tahun belakangan. Tuntutan masyarakat dan perkembangan demokrasi serta derasnya arus globalisasi dan pasar bebas, sehingga memunculkan kesadaran dari dunia industri tentang pentingnya melaksanakan tanggung jawab sosial perusahaan CSR (Corporate Social Responsibility). Pikiran-pikiran yang menyatakan kontra terhadap pengaturan CSR (Corporate Social Responsibility) menjadi sebuah kewajiban, disinyalir dapat menghambat iklim investasi baik bagi perseroan yang sudah ada maupun yang akan masuk ke Indonesia. Atas dasar berbagai pro dan kontra itulah tulisan ini diangkat untuk memberikan urun rembug terhadap pemahaman CSR (Corporate Social Responsibility) dalam perspektif kewajiban hukum. Maka pelaku bisnis, atau pihak perusahaan harus menerapkan CSR (Corporate Social Responsibility) dalam menjalankan dunia usahanya. Dengan berdirinya suatu perusahaan di Kec. Ujung Loe Kab. Bulukumba yang sudah lama beroperasi, apakah perusahaan tersebut menjalankan CSR (Corporate Social Responsibility) yang telah diatur sesuai dengan peraturan perundang-undangan.

Dalam program pelaksanaan kegiatan CSR (Corporate Social Responsibility) PT Lonsum Kab. Bulukumba yaitu untuk membantu kelancaran pelaksanaan pendidikan di Bulukumba terutama di kec. Ujung Loe seperti telah banyak dilakukan selama ini, pembangunan sekolah dasar di
Desa Pitujung, tiga ruangan, bantuan buku di sekitar Balombessie, Palangisan, bantuan beasiswa dari SD, SMP, dan SMA yang sudah berjalan dua tahun dan mengadakan pelatihan terhadap guru-guru mulai dari TK, SD, SMP dan SMA yang hingga kini terus berjalan. Hasil Program Penilaian Peringkat Perusahaan (PROPER) 20042005 Kementerian Negara Lingkungan Hidup menunjukkan bahwa dari 466 perusahaan dipantau ada 72 perusahaan mendapat rapor hitam, 150 merah, 221 biru, 23 hijau, dan tidak ada yang berperingkat emas. Dengan begitu banyaknya perusahaan yang mendapat rapor hitam dan merah, menunjukkan bahwa mereka tidak menerapkan tanggung jawab lingkungan. Disamping itu dalam prakteknya tidak semua perusahaan menerapkan CSR (Corporate Social Responsibility). Bagi kebanyakan perusahaan, CSR (Corporate Social Responsibility) dianggap sebagai parasit yang dapat membebani biaya "capital maintenance". Kalaupun ada yang melakukan CSR (corporate Social Responsibility) itupun dilakukan untuk adu gengsi. Jarang ada CSR (Corporate Social Responsibility) yang memberikan kontribusi langsung kepada masyarakat. Selain itu, kegiatan CSR (Corporate Social Responsibility) PT. Lonsum juga meliputi bidang keagamaan, infrastruktur, kesehatan, pemberdayaan masyarakat, berupa studi banding, pembinaan plasma karet, UKM Pallet Pabrik. Lonsum juga merupakan salah satu penyumbang pajak terbesar di Bulukumba. Besarannya Rp 1,8 miliar pertahunnya.

Dalam kurung waktu dua tahun yaitu tahun 2008 dan 2009 kontribusi pajak Lonsum Rp 4,5 miliar yang terdiri dari pajak bumi dan bangunan, serta pajak $P P h$. Dari segi penyerapan tenaga kerja, Lonsum Bulukumba mempekerjakan 2000 lebih, dan hampir $80 \%$ adalah putra daerah. Belum lagi yang tersebar di luar Sulsel dan 
menempati posisi yang bagus di Lonsum, PT Lonsum Bulukumba, menyerahkan bantuan dari program CSR (Corporate Social Responsibility) kepada Pemerintah Kabupaten (Pemkab) Bulukumba. Bantuan dari program CSR (Corporate Social Responsibility) PT Lonsum berupa sumur bor di Desa Bontominasa dan Desa Tibona, rehabilitasi sekolah MIS di Desa Pattiroang, perbaikan jalan di sekitar area perkebunan karet, bantuan kepada masyarakat tidak mampu dan sumbangan terhadap pembangunan masjid di Kec. Ujung Loe, serta bantuan kepada tenaga honorer. Program CSR (Corporate Social Responsibility) dari PT Lonsum senilai Rp 200 juta lebih. Penyerahan bantuan perbaikan infrastruktur dari PT Lonsum itu, dilakukan Manajer PT Lonsum Balangbessie Estate.

\section{B. TINJAUAN PUSTAKA}

Secara khusus badan usaha Perseroan Terbatas diatur dalam Undang-Undang No. 40 Tahun 2007 tentang Perseroan Terbatas (UUPT), yang secara efektif berlaku sejak tanggal 16 Agustus 2007. Sebelum UUPT 2007, berlaku UUPT No. 1 Th 1995 yang diberlakukan sejak 7 Maret 1996 (satu tahun setelah diundangkan) sampai dengan 15 Agustus 2007, UUPT tahun 1995 tersebut sebagai pengganti ketentuan tentang perseroan terbatas yang diatur dalam KUHD Pasal 36 sampai dengan Pasal 56, dan segala perubahannya(terakhir dengan UU No. 4 Tahun 1971 yang mengubah sistem hak suara para pemegang saham yang diatur dalam Pasal 54 KUHD dan Ordonansi Perseroan Indonesia atas saham Ordonantie op de Indonesische Maatschappij op Aandeelen (IMA) diundangkan dalam Staatsblad 1939 No. 569 jo 717.

Undang-Undang Penanaman Modal Nomor 25 Tahun 2007 Peraturan lain yang mewajibkan CSR (Corporate Social Responsibility) adalah Undang-Undang Nomor 25 Tahun 2007, tentang Penanaman
Modal, baik penanaman modal dalam negeri, maupun penenaman modal asing. Dalam Pasal 15 (b) dinyatakan bahwa setiap penanam modal berkewajiban melaksanakan tanggung jawab sosial perusahaan. Sanksi-sanksi terhadap badan usaha atau perseorangan yang melanggar peraturan, diatur dalam Pasal 34, yaitu berupa sanksi administratif dan sanksi lainnya, diantaranya: (1) Peringatan tertulis; (2) Pembatasan kegiatan usaha; (3) Pembekuan kegiatan usaha dan/atau fasilitas penanaman modal atau; (4) Pencabutan kegiatan usaha atau fasilitas penanaman modal maupun untuk tidak melaksanakan sesuatu.

Pengertian ini menyamakan kebijakan pemerintah dengan tindakantindakan pemerintah, dan memandang setiap pilihan tindakan yang dilakukan oleh pemerintah sudah tentu memiliki tujuan dan Berdasarkan Pasal 1 UUPT No. 40/2007 pengertian Perseroan Terbatas Perseroan adalah badan hukum yang merupakan persekutuan modal, didirikan berdasarkan perjanjian, melakukan kegiatan usaha dengan modal dasar yang seluruhnya terbagi dalam saham, dan memenuhi persyaratan yang ditetapkan dalam undang-undang ini serta peraturan pelaksanaannya. Berikut bentuk perbedaan PT dengan CV. PT merupakan badan usaha yang berbentuk badan hukum yang merupakan persekutuan modal didrikan berdasarkan perjanjian dan melakukan kegiatan usaha dengan modal dasar yang seluruhnya, terbagi dalam saham UU. No. 40 tahun 2007. Tentang PT UUPT. Dengan status yang demikian itu, PT menjadi subyek hukum yang menjadi pendukung hak dan kewajiban, sebagai badan hukum. Hal ini berarti PT. dapat melakukan perbuatan-perbuatan hukum seperti seorang manusia dan dapat pula mempunyai kekayaan atau utang (ia bertindak dengan perantaraan pengurusnya). $\mathrm{CV}$ atau Commanditaire Vennontschap yang biasa disebut 
Persekutuan Komanditer adalah suatu Perusahaan yang didirikan oleh satu atau beberapa orang secara tanggung menanggung, bertanggung jawab secara seluruhnya atau secara solider, dengan satu orang atau lebih sebagai pelepas uang (Geldschieter), dan diatur dalam KUHD. CV pada konsepnya merupakan permitraan yang terdiri dari satu atau lebih mitra biasa dan satu atau lebih mitra diam (Komanditer), yang secara pribadi bertanggung jawab untuk semua utang permitraan, dan bertanggung jawab hanya sebesar kontribusinya. Kehadiran mitra diam adalah ciri utama dari $\mathrm{CV}$ atau permitraan terbatas.

Secara konseptual, pemberdayaan atau pemberkuasaan (empowerment), Berasal dari kata power (kekuasaan atau keberdayaan). Karenanya, ide utama pemberdayaan bersentuhan dengan konsep mengenai kekuasaan. Kekuasaan seringkali dikaitkan dengan kemanpuan kita untuk membuat orang lain melakukan apa yang kita inginkan, terlepas dari keinginan dan minat mereka. Ilmu sosial tradisional menekankan bahwa kekuasaan berkaitan dengan pengaruh dan kontrol.

Para ilmuwan sosial dalam memberikan pengertian pemberdayaan mempunyai rumusan yang berbeda-beda dalam berbagai konteks dan bidang kajian, hal tersebut dikarenakan belum ada definisi yang tegas mengenai konsep pemberdayaan. Oleh karena itu, agar dapat memahami secara mendalam tentang pengertian pemberdayaan maka perlu mengkaji beberapa pendapat para ilmuwan yang memiliki komitmen terhadap pemberdayaan masyarakat.

Pertama akan kita pahami pengertian tentang pemberdayaan. Menurut Sulistiyani (2004 : 77) secara etimologis pemberdayaan berasal dari kata dasar daya yang berarti kekuatan atau kemampuan. Bertolak dari pengertian tersebut, maka pemberdayaan dapat dimaknai sebagai suatu proses menuju berdaya atau proses pemberian daya (kekuatan/kemampuan) kepada pihak yang belum berdaya. Kedua pengertian tentang masyarakat menurut Soetomo (2011 : 25) masyarakat adalah sekumpulan orang yang saling berinteraksi secara kontinyu, sehingga terdapat relasi sosial yang terpola, terorganisasi.

Dari kedua definisi tersebut bila digabungkan dapat dipahami makna pemberdayaan masyarakat. Namun sebelum kita tarik kesimpulan, terlebih dahulu kita pahami makna pemberdayaan masyarakat menurut para ahli. Menurut Aziz, (2005 : 136) Pemberdayaan masyarakat merupakan suatu proses di mana masyarakat, khususnya mereka yang kurang memiliki akses ke sumber daya pembangunan, didorong untuk meningkatkan kemandiriannya di dalam mengembangkan perikehidupan mereka. Pemberdayaan masyarakat juga merupakan proses siklus terus-menerus, proses partisipatif di mana anggota masyarakat bekerja sama dalam kelompok formal maupun informal untuk berbagi pengetahuan dan pengalaman serta berusaha mencapai tujuan bersama. Jadi, pemberdayaan masyarakat lebih merupakan suatu proses".

Lebih lanjut pemaknaan pemberdayaan masyarakat menurut Madekhan (2007 : 86) yang mendefinisikan pemberdayaan masyarakat sebagai berikut ini Pemberdayaan masyarakat sebagai sebuah bentuk partisipasi untuk membebaskan diri mereka sendiri dari ketergantungan mental maupun fisik. Partisipasi masyarakat menjadi satu elemen pokok dalam strategi pemberdayaan dan pembangunan masyarakat, dengan alasan pertama, partisipasi masyarakat merupakan satu perangkat ampuh untuk memobilisasi sumber daya lokal, mengorganisir serta membuka tenaga, kearifan, dan kreativitas masyarakat. Kedua, partisipasi masyarakat juga membantu upaya identifikasi dini terhadap kebutuhan masyarakat. 
Mengacu pada pengertian dan teori para ahli di atas, dalam penelitian ini pemberdayaan dapat diartikan sebagai upaya membangkitkan kesadaran akan potensi yang dimiliki serta berupaya untuk mengembangkannya sehingga masyarakat dapat mencapai kemandirian. Kemudian dapat disimpulkan bahwa pemberdayaan masyarakat adalah upaya untuk meningkatkan daya atau kekuatan pada masyarakat dengan cara memberi dorongan, peluang, kesempatan, dan perlindungan dengan tidak mengatur dan mengendalikan kegiatan masyarakat yang diberdayakan untuk mengembangkan potensinya sehingga masyarakat tersebut dapat meningkatkan kemampuan dan mengaktualisasikan diri atau berpartisipasi melalui berbagai aktivitas.

Tujuan yang ingin dicapai dari pemberdayaan masyarakat menurut Sulistiyani (2004 : 80) adalah untuk membentuk individu dan masyarakat menjadi mandiri. Kemandirian tersebut meliputi kemandirian berfikir, bertindak, dan mengendalikan apa yang mereka lakukan tersebut. Untuk mencapai kemandirian masyarakat diperlukan sebuah proses. Melalui proses belajar maka secara bertahap masyarakat akan memperoleh kemampuan atau daya dari waktu ke waktu.

Berikut tujuan pemberdayaan menurut Tjokowinoto (2005: 16) yang dirumuskan dalam 3 (tiga) bidang yaitu ekonomi, politik, dan sosial budaya. Kegiatan pemberdayaan harus dilaksanakan secara menyeluruh mencakup segala aspek kehidupan masyarakat untuk membebaskan kelompok masyarakat dari dominasi kekuasan yang meliputi bidang ekonomi, politik, dan sosial budaya. Konsep pemberdayaan dibidang ekonomi adalah usaha menjadikan ekonomi yang kuat, besar, mandiri, dan berdaya saing tinggi dalam mekanisme pasar yang besar dimana terdapat proses penguatan golongan ekonomi lemah.
Sedang pemberdayaan dibidang politik merupakan upaya penguatan rakyat kecil dalam proses pengambilan keputuan yang menyangkut kehidupan berbangsa dan bernegara khususnya atau kehidupan mereka sendiri. Konsep pemberdayaan masyarakat di bidang sosial budaya merupakan upaya penguatan rakyat kecil melalui peningkatan, penguatan, dan penegakan nilai-nilai, gagasan, dan normanorma, serta mendorong terwujudnya organisasi sosial yang mampu memberi kontrol terhadap perlakuan-perlakuan politik dan ekonomi yang jauh dari moralitas.

Dari paparan tersebut dapat kita simpulkan bahwa tujuan pemberdayaan adalah memampukan dan memandirikan masyarakat terutama dari kemiskinan, keterbelakangan, kesenjangan, dan ketidak berdayaan. Kemiskinan dapat dilihat dari indikator pemenuhan kebutuhan dasar yang belum mencukupi/layak. Kebutuhan dasar itu, mencakup pangan, pakaian, papan, kesehatan, pendidikan, dan transportasi. Sedangkan keterbelakangan, misalnya produktivitas yang rendah, sumberdaya manusia yang lemah, kesempatan pengambilan keputusan yang terbatas.

Kemudian ketidak berdayaan adalah melemahnya kapital sosial yang ada di masyarakat (gotong royong, kepedulian, musyawarah, dan kswadayaan) yang pada gilirannya dapat mendorong pergeseran perilaku masyarakat yang semakin jauh dari semangat kemandirian, kebersamaan, dan kepedulian untuk mengatasi persoalannya secara bersama.

Berdasarkan pendapat Sunyoto (2003: 40-47) ada beberapa strategi yang dapat menjadi pertimbangan untuk dipilih dan kemudian diterapkan dalam pemberdayaan masyarakat, yaitu menciptakan iklim, memperkuat daya, dan melindungi. Dalam upaya memberdayakan masyarakat dapat dilihat dari tiga sisi, yaitu Menciptakan suasana atau iklim yang 
memungkinkan potensi masyarakat berkembang (enabling). Disini titik tolaknya adalah pengenalan bahwa setiap manusia memiliki potensi atau daya yang dapat dikembangkan. Memperkuat potensi atau daya yang dimiliki masyarakat (empowering), upaya yang amat pokok adalah peningkatan taraf pendidikan, dan derajat kesehatan, serta akses ke dalam sumber-sumber kemajuan ekonomi seperti modal, lapangan kerja, dan pasar.

Berbicara tentang pendekatan, bila dilihat dari proses dan mekanisme perumusan program pembangunan masyarakat, pendekatan pemberdayaan cenderung mengutamakan alur dari bawah ke atas atau lebih dikenal pendekatan bottom-up. Pendekatan ini merupakan upaya melibatkan semua pihak sejak awal, sehingga setiap keputusan yang diambil dalam perencanaan adalah keputusan mereka bersama, dan mendorong keterlibatan dan komitmen sepenuhnya untuk melaksanakannya.

Partisipasi masyarakat sangat dibutuhkan dalam rangka perencanaan dan penentuan kebijakan, atau dalam pengambilan keputusan. Model pendekatan dari bawah mencoba melibatkan masyarakat dalam setiap tahap pembangunan. Pendekatan yang dilakukan tidak berangkat dari luar melainkan dari dalam. Seperangkat masalah dan kebutuhan dirumuskan bersama, sejumlah nilai dan sistem dipahami bersama. Model bottom memulai dengan situasi dan kondisi serta potensi lokal. Dengan kata lain model kedua ini menampatkan manusia sebagai subyek. Pendekatan bottom up lebih memungkinkan penggalian dana masyarakat untuk pembiayaan pembangunan.

Hal ini disebabkan karena masyarakat lebih merasa "memiliki", dan merasa turut bertanggung jawab terhadap keberhasilan pembangunan, yang notabene memang untuk kepentingan mereka sendiri. Betapa pun pendekatan bottom-up memberikan kesan lebih manusiawi dan memberikan harapan yang lebih baik, namun tidak lepas dari kekurangannya, model ini membutuhkan waktu yang lama dan belum menemukan bentuknya yang mapan.

Untuk melakukan pemberdayaan masyarakat secara umum dapat diwujudkan dengan menerapkan prinsipprinsip dasar pendampingan masyarakat, sebagai berikut: Belajar dari masyarakat Prinsip yang paling mendasar adalah prinsip bahwa untuk melakukan pemberdayaan masyarakat adalah dari, oleh, dan untuk masyarakat. Ini berarti, dibangun pada pengakuan serta kepercayaan akan nilai dan relevansi pengetahuan tradisional masyarakat serta kemampuan masyarakat untuk memecahkan masalah-masalahnya sendiri.

Pendamping sebagai Fasilitator Masyarakat sebagai pelaku konsekuensi dari prinsip pertama adalah perlunya pendamping menyadari perannya sebagai fasilitator dan bukannya sebagai pelaku atau guru. Untuk itu perlu sikap rendah hati serta ketersediaan untuk belajar dari masyarakat dan menempatkan warga masyarakat sebagai narasumber utama dalam memahami keadaan masyarakat itu. Bahkan dalam penerapannya masyarakat dibiarkan mendominasi kegiatan. Kalaupun pada awalnya peran pendamping lebih besar, harus diusahakan agar secara bertahap peran itu bisa berkurang dengan mengalihkan prakarsa kegiatan-kegiatan pada warga masyarakat itu sendiri.

Saling belajar Saling berbagi pengalaman salah satu prinsip dasar pendampingan untuk pemberdayaan masyarakat adalah pengakuan akan pengalaman dan pengetahuan tradisional masyarakat. Hal ini bukanlah berarti bahwa masyarakat selamanya benar dan harus dibiarkan tidak berubah. Kenyataan objektif telah membuktikan bahwa dalam banyak hal perkembangan pengalaman dan pengetahuan tradisional masyarakat tidak sempat mengejar perubahan-perubahan 
yang terjadi dan tidak lagi dapat memecahkan masalah-masalah yang berkembang. Namun sebaliknya, telah terbukti pula bahwa pengetahuan modern dan inovasi dari luar yang diperkenalkan oleh orang luar tidak juga memecahkan masalah mereka.

Terdapat manfaat yang didapatkan dari pelaksanaan tanggung jawab sosial perusahaan, baik bagi perusahaan sendiri, bagi masyarakat, pemerintah dan pemangku kepentingan lainnya. Wibisono (2007, hal 99) menguraikan manfaat yang akan diterima dari pelaksanaan CSR (Corporate Social Responsibility) diantaranya Terdapat empat manfaat yang diperoleh perusahaan dengan mengimplementasikan CSR (Corporate Social Responsibility): Pertama, keberadaan perusahaan dapat tumbuh dan berkelanjutan dan perusahaan mendapatkan citra yang positif dari masyarakat luas. Kedua, perusahaan lebih mudah memperoleh akses terhadap modal (capital). Ketiga, perusahaan dapat mempertahankan sumber daya manusia (human resources) yang berkualitas. Keempat, perusahaan dapat meningkatkan pengambilan keputusan pada hal-hal yang kritis (critical decision making) dan mempermudah pengelolaan manajemen risiko (risk management), Bagi masyarakat, praktik CSR (Corporate Social Responsibility) yang baik akan meningkatkan nilai-tambah adanya perusahaan di suatu daerah karena akan menyerap tenaga kerja, meningkatkan kualitas sosial di daerah tersebut. Pekerja lokal yang diserap akan mendapatkan perlindungan akan hak-haknya sebagai pekerja. Jika terdapat masyarakat adat atau masyarakat lokal, praktek CSR (Corporate Social Responsibility) akan mengharagai keberadaan tradisi dan budaya lokal tersebut.

Bagi lingkungan, praktik CSR (Corporate Social Responsibility) akan mencegah eksploitasi berlebihan atas sumber daya alam, menjaga kualitas lingkungan dengan menekan tingkat polusi dan justru perusahaan terlibat mempengaruhi lingkungannnya, bagi Negara, praktik CSR (Corporate Social Responsibility) yang baik akan mencegah apa yang disebut "corporate misconduct" atau malpraktik bisnis seperti penyuapan pada aparat negara atau aparat hukum yang memicu tingginya korupsi. Selain itu, negara akan menikmati pendapatan dari pajak yang wajar (yang tidak digelapkan) oleh perusahaan.

Salah satu motif perusahaan dalam melaksanakan CSR (Corporate Social Responsibility) dan menjadi bagian penting adalah menjalin hubungan yang baik dengan regulator. Perusahaan berdiri berdasarkan izin yang diberikan pemerintah, dan diharapkan mampu berkontribusi dalam pembangunan melalui pembayaran kewajiban berupa pajak dan lainnya, juga secara sadar turut membangun kepedulian terhadap meningkatkan kesejahteraan masyarakat dan lingkungan.

$\begin{array}{ccc}\text { Keterlibatan } & \text { perusahaan dalam } \\ \text { program CSR } & \text { (Corporate Social }\end{array}$
Responsibility ) dilatar belakangi dengan beberapa kepentingan. Menurut Mulyadi (2003, hal 4) setidaknya bisa diidentifikasi tiga motif keterlibatan perusahaan, yaitu: motif menjaga keamanan fasilitas produksi, motif mematuhi kesepakatan kontrak kerja, dan motif moral untuk memberikan pelayanan sosial pada masyarakat lokal.

Pada umumnya perusahaan di Indonesia menjalankan CSR (Corporate Social Responsibility) atas dasar memenuhi kewajiban kontraktual, dalam hal ini mematuhi peraturan baik yang dibuat oleh pemerintah pusat maupun daerah. Secara normatif, idealnya tanpa adanya protes dan kewajiban kontraktual, perusahaan seharusnya berusaha memberdayakan masyarakat lokal dan meningkatkan kesejahteraan. Ide mengenai konsep CSR (Corporate Social Responsibility) juga 
dilandasi pemikiran demikian (UN Global Compact, hal. 20). Secara filantropis perusahaan seharusnya mendistribusikan keuntungan setelah mereka memanfaatkan resources di lokasi dimana masyarakat berada. Hal ini adalah kewajiban moral, namun motif yang didasarkan pada komitmen moral tersebut masih sebatas wacana dan belum terlihat nyata. Mulyadi dalam tulisan yang berjudul Pengelolaan Program Corporate Social Responsibilty: Pendekatan, Keberpihakan, dan Keberlanjutannya (2003, hal.5). Membagi stakeholders berdasarkan kepentingannya.

Dalam konteks hubungan kemitraan antara pemerintah dengan perusahaan, pemerintah daerah mengharapkan agar program-program CSR (Corporate Social Responsibility) bisa membantu menyelesaikan permasalahan sosial, seperti masalah pengangguran, kemiskinan, masalah pendidikan, kesehatan, perumahan. Selain itu menyelesaikan masalah lingkungan yang dihadapi pemerintah daerah. Hal ini menunjukkan bahwa perusahaan swasta dituntut untuk membantu pemerintah daerah untuk mendukung program pembangunan regional yang diimplementasikannya.

$\begin{array}{llr}\text { Pemerintah yang } & \text { menjadi } \\ \text { penanggung jawab utama } & \text { dalam } \\ \text { mensejahterakan } & \text { masyarakat } & \text { dan }\end{array}$ melestarikan lingkungan tidak akan menanggung beban tersebut jika dilakukan sendiri, melainkan membutuhkan partisipasi, salah satunya yang paling potensial adalah dari perusahaan, agar akselerasi pembangunan dan peningkatan kesejahteraan masyarakat bisa tercapai.

Implementasi CSR (Corporate Social Responsibility) diperusahaan pada umumnya dipengaruhi beberapa faktor (Wibisono, 2007). Pertama, terkait dengan komitmen pemimpinnya. Perusahaan yang pimpinannya tidak tanggap dengan masalah sosial, jangan harap mempedulikan maslah sosial. Kedua, menyangkut ukuran dan kematangan perusahaan. Ketiga, regulasi dan system perpajalan yang diatur pemerintah. Semakin kondusif regulasi atau semakin besar insentif pajak yang diberikan, akan lebih berpotensi member semangat kepada perusahaan untuk berkontribusi kepada masyarakat.

Secara garis besar dapat disimpulkan bahwa model implementasi CSR (Corporate Social Responsibility) perusahaan di Indonesia mencakup hal-hal berikut. Bantuan sosial meliputi bakti sosial, pengadaan sarana kesehatan, rumah ibadah, jalanan sarana umum lainnya, penanggulangan bencana alam pemberantasan kemiskinan dan pembinaan masyarakat.

Pendidikan dan pengembangan meliputi penggadaan sarana pendidikan dan pelatihan, melaksanakan pelatihan dan memberikan program beasiswa kepada anak-anak usia sekolah, ekonomi meliputi mengadakan program kemitraan, memberikan dana atau pinjaman lunak untuk pengembangan usaha dan memberdayakan masyarakat sekitar. Lingkungan meliputi pengelolaan lingkungan, penanganan limbah, melakukan reklamasi, dan melestarikan alam dan keanekaragaman hayati. Konsumen meliputi perbaikan produk secara berkesinambungan, pelayanan bebas pulsa dan menjamin ketersediaan produk. Karyawan meliputi program jaminan hari tua, keselamatan dan kesehatan kerja (K3) dan program renumerasi yang baik.

\section{METODE PENELITIAN}

Lokasi penelitian dilaksanakan di Kecamatan Ujung Loe Kabupaten Bulukumba, dengan alasan dan pertimbangan bahwa dalam mengelola program CSR (Corporate Sosial Responsibility) perlu mendapatkan perhatian dari semua kalangan yang terkait, mengingat, suatu kegitan PT 
Lonsum bagaimana melakukan pengelolaan CSR (Corporate Sosial Responsibility) terhadap pemberdayaan masyarakat setempat. Alasan lain dipilih sebagai tempat penelitian karena disamping Kabupaten Bulukumba tersebut mudah dijangkau oleh peneliti. Penelitian ini bertujuan untuk memperoleh kebenaran pengetahuan yang bersifat ilmiah, melalui prosedur yang telah ditetapkan. Jenis penelitian yang digunakan adalah pendekatan deskriptif kualitatif, yaitu dimaksudkan untuk pengukuran yang cermat terhadap fenomena sosial tertentu.

Dalam penelitian ini yang dijadikan informan adalah pemerintah Kecamatan Ujung Loe dan pihak PT. Lonsum Kabupaten Bulukumba. Dengan demikian informan dalam penelitian ini adalah manajemen PT. Lonsum, masyarakat setempat, dan tokoh masyarakat.

Adapun informan dalam penelitian ini sebanyak 10 orang, yaitu: Pemerintah Kecamatan Ujung Loe Kab. Bulukumba. (1 orang) Manajemen PT. Lonsum Kec, Ujung Loe Kab. Bulukumba. (3 orang). Masyarakat sekitar pemukiman PT. Lonsum Kec. Ujung Loe kab. Bulukumba (3 orang). Tokoh masyarakat sekitar pemukiman perusahaan PT. Lonsum Kec, Ujung Loe Kab. Bulukumba, (3 orang) pemerintah daerah.

Alasan dalam memilih informan diatas dengan bertujuan agar data-data yang diperoleh mengenai pengelolaan CSR (Corporate Sosial Responsibility) tepat dan akurat tentang kebenarannya berdasarkan informan yang dipilih langsung. Analisis data dilakukan dengan menelaah data yang diperoleh dari berbagai sumber atau informasi dari hasil penelitian peran pemerintah daerah dalam mengelola CSR (Corporate Sosial Responsibility) terhadap pemberdayaan masyarakat, baik yang diperoleh melalui data primer maupun data sekunder yang dilakukan secara deskriftif kualitatif dengan didukung tabel frekuensi yang sederhana dan didukung beberapa variabel pendukung yang dijadikan indikator dalam penelitian ini.

Setelah menganalisis data, peneliti harus memastikan apakah interpretasi dan temuan penelitian akurat. Validasi temuan menurut Creswell berarti bahwa peneliti menentukan keakuratan dan kredibilitas temuan melalui beberapa strategi, antara lain member checking, triangulasi dan auditing (sugiyono, 2012: 42).

Member checking adalah proses penelitian mengajukan pertanyaan pada satu atau lebih partisipan atau tujuan seperti yang telah dijelaskan di atas. Aktifitas ini juga dilakukan untuk mengambil temuan kembali pada partisipan dan menanyakan pada mereka baik lisan maupun tulisan tentang keakuran laporan penelitian. Pertanyaan dapat meliputi berbagai aspek dalam penelitian tersebut, misalnya apakah deskripsi data telah lengkap, apakah interpretasi bersifat refresentatif dan dilakukan tanpa kecenderungan.

Triangulasi merupakan proses penyokongan bukti terhadap bukti terhadap temuan, analisis dan interpretasi data yang telah dilakukan peneliti yang berasal dari: 1) individu (informan) 2) tipe atau member data (wawancara, pengamatan dan dokumen), serta 3) metode pengumpulan data (wawancara, pengamatan dan dokumen). External audit, yaitu untuk menghindari biasa atau hasil temuan penelitian, peneliti perlu melakukan cek silang dengan seseorang diluar penelitian. Seseorang tersebut dapat berupa pakar yang dapat memberikan penilaian imbang dalam bentuk pemeriksaan laporan penelitian yang akurat.

\section{HASIL PENELITIAN DAN PEMBAHASAN}

CSR (Corporate Social Responsibility) merupakan suatu komitmen berkelanjutan oleh dunia usaha untuk bertindak etis dan memberikan kontribusi kepada 
pengembangan ekonomi dari komunitas setempat ataupun masyarakat luas, bersaman dengan peningkatan taraf hidup pekerja beserta keluarganya (Wibisono, 2007, h.7). Terdapat beberapa definisi lain mengenai CSR (Corporate Social Responsibility). Dari sekian banyak definisi CSR (Corporate Social Responsibility) salah satu yang menggambarkan CSR (Corporate Social Responsibility) di Indonesia adalah definisi Suharto (2006) yang menyatakan bahwa CSR (Corporate Social Responsibility) adalah operasi bisnis yang berkomitmen tidak hanya untuk meningkatkan keuntungan perusahaan secara finansial, melainkan pula untuk membangun sosial ekonomi kawasan secara holistik, melembaga dan berkelanjutan. Dari definisi tersebut, dapat kita lihat bahwa salah satu aspek yang dalam pelaksanaan CSR (Corporate Social Responsibility) adalah komitmen berkelanjutan dalam mensejahterakan komunitas lokal masyarakat sekitar.

\section{PENGELOLAAN CORPORATE SOCIAL RESPONSIBILITY PT LONSUM DI KECAMATAN UJUNG LOE KABUPATEN BULUKUMBA}

Dalam pengelolaan CSR (Corporate Social Responsibility) PT. LONSUM di Kec, Ujung Loe Kab. Bulukumba. Program CSR (Corporate Social Responsibility) merupakan investasi bagi perusahaan demi pertumbuhan dan keberlanjutan (sustainability) perusahaan dan bukan lagi dilihat sebagai sarana biaya (cost centre) melainkan sebagai sarana meraih keuntungan (profit centre). Program CSR (Corporate Social Responsibility) merupakan komitmen perusahaan untuk mendukung terciptanya pembangunan berkelanjutan (sustainable development).

Undang-Undang Penanaman Modal Nomor 25 Tahun 2007 Peraturan lain yang mewajibkan CSR (Corporate Social Responsibility) adalah Undang-Undang Nomor 25 Tahun 2007, tentang Penanaman Modal, baik penanaman modal dalam negeri, maupun penenaman modal asing. Dalam Pasal 15 (b) dinyatakan bahwa setiap penanam modal berkewajiban melaksanakan tanggung jawab sosial perusahaan.

Pelaksanaan (Actuating) adalah suatu tindakan untuk mengusahakan agar semua agar semua anggota kelompok berusaha untuk mencapaisasaran yang sesuai dengan perencanaan manejerial dan usahausahaorganisasi. Jadi actuating artinya menggerakkan orang-orang agar mau bekerja dengan sendirinya atau dengan kesadaran secarabersama-sama untuk mencapai tujuan dikehendaki secara efektif.

Dalam pelaksanaan CSR (Corporate Social Responsibility) bahwa tidak semua masyarakat dilibatkan dalam perencanaan tetapi ada perwakilan tersendiri dari masyarakat yang membahas tentang perenacanaan-perencanaan kegiatan CSR (Corporate Social Responsibility) masyarakat pada umumnya hanya diinfokan oleh pihak perusahan sebelum kegiatan tersebut dilaksanakan.

Seperti dengan tanggapan oleh manajer PT. LONSUM itu sendiri bahwa dalam setiap perencanan- perencanan pembahasan kegiatan CSR (Corporate Social Responsibility) yang akan dilakukan, tokoh masyarakat dan masyarakat itu sendiri dilibatkan didalamnya untuk memberikan masukan terkait dengan pembahasan kegiatan CSR (Corporate Social Responsibility) yang dilakukan oleh pihak perusahaan supaya dalam programprogram yang akan dilaksanakannya dapat diberikan dukungan oleh tokoh masyarakat dan masyarakat itu sendiri. Dengan adanya suatu dukungan oleh masyarakat tentunya akan memberikan power terhadap perusahan itu sendiri serta akan memberikan citra positif bagi perusahaan.

Beberapa informan yang diwawancarai berbeda, perusahan PT. LONSUM dapat dikatakan melibatkan semua kalangan baik pemerintah setempat, tokoh masyarakat dan masyarakt itu 
sendiri dalam tahap perencanaan kegiatankegiatan CSR (Corporate Social Responsibility) yang akan dilaksanakannya. Ini sesuai dengan konsep pserencanaan itu sendiri Perencanaan adalah cara berpikir mengenai persoalan-persoalan sosial dan ekonomi, terutama berorientasi pada masa datang, berkembang dengan hubungan antara tujuan dan keputusan-keputusan kolektif dan mengusahakan kebijakan dan program. Dengan melibatkannya pemerintah, tokoh masyarakat dan masyarakat itu sendiri dapat membuahkan hasil keputusan-keputusan yang secara kolektif yang dapat memberikan manfaat bagi peusahaan, pemerintah dan masyarakat.

Dapat dikatakan bahwa pihak PT. LONSUM mengikiut sertakan semua elemen yang terkait didalmnya baik pemerintah, tokoh masyarakat dan masyarakat itu sendiri. Ini menjadi suatu tolak ukur bahwa perusahaan melibatkan semua kalangan dalam melakukan suatu kegiatan perencanaan tangung jawab sosial CSR (Corporate Social Responsibility).

Berdasarkan dengan suatu kegiatan CSR (Corporate Social Responsibility) yang dilakukan oleh pihak perusahaan meliputi kegiaatan dalam bidang pemberdayaan masyarakat seperti pembangunan jalan sepanjang area perkebunan, bantuan sembako terhadap masyarakat kurang mampu dalam bidang pendidikan yaitu memberikan bantuan beasiswa terhadap siswa yang kurang mampu hingga perguruan tinggi dan memberikan prasarana pendidikan. Dalam bidang kesehatan melakukan sunatan massal dalam bidang lingkunagan yaitu melakukan penanaman pohon dan dalam bidang ekonomi dengan memperkerjakannya putra-putri daerah sehingga mampu memberikan peningkatan ekonomi masyarakat. Kebanyakn masyarakat, tokoh masyarakat dan pemerintah itu sendiri mendukung dengan kegiatan CSR
(Corporate Social Responsibility) yang dilakukan oleh PT. LONSUM.

Dalam pelaksanan CSR (Corporate Social Responsibility) yang dilakukan oleh PT. LONSUM sesuai dengan konsep tanggung jawab sosial perusahaan dimana pihak perusahaan harus fokus memberdayakan masyarakat lewat dengan kegiatan-kegiatan CSR (Corporate Social Responsibility) yang dilakukan oleh pihak perusahaan. Lewat dengan kegitan yang dilkukan oleh pihak perusahaan, pemerintah tokoh masyarakat dan masyarakat sangat mendukung sepenuhnya terkait dengan kegiatan CSR (Corporate Social Responsibility) karena msyarakat merasa diberdayakan oleh pihak perusahaan. Salah satu motif perusahaan dalam melaksanakan CSR (Corporate Social Responsibility) dan menjadi bagian penting adalah menjalin hubungan yang baik dengan regulator. Perusahaan berdiri berdasarkan izin yang diberikan pemerintah, dan diharapkan mampu berkontribusi dalam pembangunan melalui pembayaran kewajiban berupa pajak dan lainnya, juga secara sadar turut membangun kepedulian terhadap meningkatkan kesejahteraan masyarakat dan lingkungan.

Pada masyarakat umum, bahwa di dalam benak masyarakat tertanam bahwa perusahaan adalah pemilik modal, mereka berbisnis; dan untuk itu perusahaan harus share keuntungan dia untuk masyarakat. Dari yang simpel, misalnya perusahaan dimintai sumbangan sponsor kegiatan mahasiswa, pembangunan masjid, dan sebagainya. Praktik semacam ini telah tumbuh lama bahkan sejak sebelum istilah CSR (Corporate Social Responsibility) itu sendiri muncul. Hanya sekarang kan variasinya sudah sangat kompleks dan beragam, ditujukan pada pemberdayaan komunitas yang lebih signifikan. Perteori, orang pun lalu mengaitkan CSR (Corporate Social Responsibility) dengan praktik bisnis 
perusahaan yang sangat masif, eksploitatif, dan ekstraktif yang mempengaruhi keseimbangan alam dan sosial. Sehingga bisnis harus bertanggung jawab terhadap perubahan keseimbangan tersebut sebagai ekses dari praktik bisnis yang dilakukannya, ini yang kemudian dikonsep tualisasikan dengan tanggung jawab sosial perusahaan bisnis atau CSR (Corporate Social Responsibility). Pengawasan adalah proses dalam menetapkan ukuran kinerja dan pengambilan tindakan yang dapat mendukung pencapaian hasil yang diharapkan sesuai dengan kinerja yang telah ditetapkan tersebut. Controlling is the process of measuring performance and taking action to ensure desired results. Pengawasan adalah proses untuk memastikan bahwa segala aktifitas yang terlaksana sesuai dengan apa yang telah direncanakan.

Dalam pengawasan pengelolaan CSR yang dilakukan oleh PT. LONSUM pihak perusahaan melibatkan pemerintah masyarakat dan tokoh masyarakat itu sendiri Berdasarkan hasil reduksi data yang dideskripsikan diatas maka peneliti dapat menyimpulkan bahwa dalam bentuk pengawasan yang dilakukan oleh pihak PT. LONSUM melibatkan semua dengan pihak yang terkait didalamnya mulai dari pemerintah setempat, tokoh masyaarakat dan masyarakat itu sendiri tetapi dalam hal ini tidak semua masyarakat dan tokoh masyarakat terjun langsung dalam pengawasan tersebut ada perwakilan dari masyarakt itu sendiri tetapi secara tidak langsung masyarakat ikut serta dalam pengawasan suatu kegiatan tersebut. Dari hasil wawancara dengan beberpa informan tidak ada bentuk perbedaan jawaban dari semua responden tentang pengawasan.

\section{MANFAAT CSR (CORPORATE SOSIAL RESPONSIBILITY) PADA MASYARAKAT KEC. UJUNG LOE KAB. BULUKUMBA}

Manfaat CSR (Corporate Sosial Responsibility) bagi masyarakat adalah akan meningkatkan nilai-tambah adanya perusahaan di suatu daerah karena akan menyerap tenaga kerja, meningkatkan kualitas sosial di daerah tersebut. Pekerja lokal yang diserap akan mendapatkan perlindungan akan hak-haknya sebagai pekerja. Jika terdapat masyarakat adat atau masyarakat lokal, praktek CSR (Corporate Sosial Responsibility) akan mengharagai keberadaan tradisi dan budaya lokal tersebut.

Dari masyarakat sendiri merasakan manfaat dengan keberadaanya PT. LONSUM di desa mereka dengan mempekerjakan masyarakat di perusahaan tersebut sehingga dapat meringankan beban mereka. Intinya manfaat CSR (Corporate Sosial Responsibility)bagi masyarakat yaitu dapat mengembangkan diri dan usahanya sehingga sasaran untuk mencapai kesejahteraan tercapai. Bahwa salah satu aspek yang dalam pelaksanaan CSR (Corporate Social Responsibility) adalah komitmen berkelanjutan dalam mensejahterakan komunitas lokal masyarakat sekitar bagi masyarakat, praktik CSR (Corporate Social Responsibility) yang baik akan meningkatkan nilai-tambah adanya perusahaan di suatu daerah karena akan menyerap tenaga kerja, meningkatkan kualitas sosial di daerah tersebut. Pekerja lokal yang diserap akan mendapatkan perlindungan akan hak-haknya sebagai pekerja. Jika terdapat masyarakat adat atau masyarakat lokal, praktek CSR (Corporate Social Responsibility) akan mengharagai keberadaan tradisi dan budaya lokal tersebut.

Dengan manfaat yang diraskan oleh masyarakat terkait dengan keberdaaan PT. LONSUM seperti dengan hasil wawancara bahwa dengan keberadaan perusahan tersebut dapat menyekolahkan anak-anak mereka serta masyarakat dapat membangun rumah sendiri dengan hasil 
upah yang mereka dapat, ini merupakan bahwa masyarakat terbantu dengan keberadaan tersebut. Dengan ukuran efektivnya suatu kegiatan CSR (Corporate Social Responsibility) yang dilakukan oleh PT. LONSUM dapat dikatakan efektiv tetapi apakah sepenuhnya efektiv bagi masyarakat yang terkait didalamnya.

Dapat dikatakan bahwa masyarakat dapat merasakan manfat yang ada seputar dengan kegiatan-kegiatan CSR (Corporate Social Responsibility) yang dilakukan oleh PT. LONSUM di Kec. Ujung Loe Kab. Bulukumba berdasarkan analisis hasil wawancara dengan beberapa informan yang terkait didalamnya sehingga dapat disimpulkan bahwa PT. LONSUM melaksanakan suatu kegiatan CSR (Corporate Social Responsibility) sesuai dengan keputusan perundang-undangan Gubernur sulawesi selatan nomor :2666 / XI tahun 2012 tentang forum komunikasi penyelenggaraan tanggung Jawab sosial perusahaan / Corporate Sosial Responsibility di Provinsi Sulawesi Selatan.

Sebagai penjabaran ketentuan Pasal

13 Peraturan Gubernur Sulawesi SelatanNomor 45 Tahun 2012 tentang Penyelenggaraan Tanggung Jawab Sosial Perusahaan / Corporate Social Responsibility di Sulawesi Selatan ditegaskan perlunya membentuk Forum Komunikas Corporate Social Responsibility.

Bahwa forum komunikasi ini dimaksudkan sebagai wadah penyerasian program Tanggung jawab sosial Perusahaan kemitraan dan bina lingkungan bagi perusahaan untuk turut berpartisipasi dalam mendukung program pembangunan daerah di Provinsi Sulawesi Selatan.

Bahwa bedasarkan pertimbangan sebagaimana dimaksud dalam huruf (a) dan huruf (b) perlu menetapkan Keputusan Gubernur Sulawesi Selatan tentang Forum Komunikasi Corporate Social Responsibility Provinsi Sulawesi Selatan.

\section{E. KESIMPULAN}

Berdasarkan hasil penelitian yang dilakukan maka penulis menyimpulkan bahwa Pengelolaan CSR (Corporate Sosial Responsibility) di Kec, Ujung Loe Kab. Bulukumba: (1)Berdasarkan hasil pengamatan penulis bahwa variabel perencanaan terhadap kegiatan CSR (Corporate Sosial Responsibility) pihak perusahaan melibatkan masyarakat dan pemerintah setempat ikut serta dalam melakukan suatu perencanaan; (2)Pelaksanaan dengan indikator bentukbentuk pelaksanaan kegiatan CSR berada pada kategori tepat sesuai dengan konsep tanggung jawab sosial perusahaan; (3)Pengawasan terhadap kegiatan CSR (Corporate Sosial Responsibility) dengan indikator pihak perusahaan melibatkan semua kalangan yang terkait didalamnya; (4)Efektifitas pengelolaan dalam suatu kegiata CSR (Corporate Sosial Responsibility) dengan indikator sangat efektif; (5)Manfaat pada masyarakat dengan indikator sangat baik dan terarah.

Upaya yang dilakukan oleh PT. LONSUM dalam pengelolaan CSR (Corporate Sosial Responsibility) di Kec, Ujung Loe Kab. Bulukumba sangat efektif sejauh ini adalah pihak perusahaan melakukan suatu kegiatan CSR (Corporate Sosial Responsibility) sesuai dengan peraturan tanggung jawab sosial perusahaan dalam UU. Perseroan terbatas tetrhadap bagaimana meberdayakan masyarakat, peningkatan ekonomi dan keselamatan lingkungan. Dapat diukur PT. LONSUM memberikan dampak positif bagi masyarakat, pemerintah dan lingukungan. Dengan berbagai bentuk CSR (Corporate Sosial Responsibility) yang dilakukannya sehingga masyarakat merasa diberdayakan. 


\section{DAFTAR PUSTAKA}

Arikunto, Suharsimi. 2008. Prosedur Penelitian: Suatu Pendekatan Praktek. Jakarta: PT Rineke.

Baitul, Hikmah .2013. bantu-perusahaantetap-hidup.Online

http://www.baitul-hikmah.com.

Diakses tanggal 03 Oktober 2013. 10:45 pm

Budi Untung, Hendrik. 2008. Corporate Sosial Responsibility. Jakarta:Sinar Grafika

Bismar, 2009. Tanggung jawab sosial perusahaan.

http://bismar.wordpress.com

Diakses tangga 105 maret 2014. 07:45 pm.

Carapedia, 2011 pengertian definisi perusahaan,Online http://carapedia.com/ Diakses tanggal 09 Desember 2013. 18: 00 $\mathrm{pm}$

Chikacimoet,2013. pemberdayaan masyarakat.Online.http://chikacimo et..com Diakses tanggal 04 Desember 2013. 18:25 pm

Corpsocialresp, 2007. Csr untuk pemberdayaan masyarakat http://corpsocialresp.blogspot.com Diakses tanggal 05 maret 2014. 07:45 pm.

Hemingway, Christine A. and Patrick W. Maclagan (2004). 'Managers' personal values as drivers of corporate social responsibility', Journal of Business Ethics, Vol. 50,

Ezoolendino, 2009. Model dan pola implementasi csr, http://ezoolendino.blogspot.com
Diakses tanggal 05 januari 2014 . 13:25 qm.

Hujau,2010 Devinisi lsm lembaga swadaya masyarakat, Online http://hujau.blogspot.com Diakses tanggal 09 Desember 2013. 18: 20 pm

Hurairah, Abu. (2008). Pengorganisasian dan Pengembangan Masyarakat. Bandung: Humaniora

Kminoz, 2012 Manfaat corporate social responsibility bagi masyarakat. http://wartawarga.gunadarma.ac.id Diakses tanggal 29 Desember 13 12:00 qm.

Majidbsz, 2008. pengertian-masyarakat. Online

http://majidbsz.wordpress.com

Diakses tanggal 09 Desember 2013. 18: $20 \mathrm{pm}$

Mulyadi (2003): Pengelolan Program Corporate Social Responsibility: Pendekatan, Keberpihakan dan Keberlanjutannya. Center for Populaton Studies.

Rahmatullah, 2012. Konsep dasar csr, http://www.rahmatullah.net

Diakses tanggal 05 januari 2014. 00:25 qm.

Rahmatullah, 2013 Regulasi-csr-diIndonesia.Online

http://www.Rahmatullah.net.

Diakses tanggal 25 Oktober 2013. 13:05 pm

Rahmatullah, dkk (2011). Panduan Praktis Pengelolaan CSR (Corporate Social Responsibility). Yogyakarta: Samudra Biru. 
Rudito, dkk (2004). Corporate Social Responsibility: Jawaban Bagi Modal Pembangunan Indonesia Masa Kini. Jakarta: ICSD

Sugiyono.2013. Metode Penelitian Pendidikan. Bandung: Alfabeta.

Suharto, Edi. 2010. Membangun Masyarakat Memberdayakan Rakyat. Bandung: Refika Aditama.

Suprapto, Siti Adipringadi Adiwoso, 2006, Pola Tanggung Jawab Sosial Perusahaan Lokal di Jakarta,
Usakti,2011,mmcsr.Online http://www.mmcsrusakti.org Diakses tanggal 17 oktober 2013. 15: $25 \mathrm{pm}$

Wardhana, Arya Wisnu 2004. Dampak Pencemaran Lingkungan, Yogjakarta. 